\title{
Article \\ The Writing Process of Bilingual Students with Focus on Revisions and Spelling Errors in Their Final Texts
}

\author{
Elisabeth Zetterholm (D) and Eva Lindström * (D) \\ Department of Culture and Society (IKOS), Linköping University, SE-581 83 Linköping, Sweden; \\ elisabeth.zetterholm@liu.se \\ * Correspondence: eva.a.lindstrom@liu.se
}

check for updates

Citation: Zetterholm, Elisabeth, and Eva Lindström. 2022. The Writing Process of Bilingual Students with Focus on Revisions and Spelling Errors in Their Final Texts. Languages 7: 61. https://doi.org/10.3390/ languages7010061

Academic Editors: Åsa Wedin, Boglárka Straszer, Juana M. Liceras and Raquel Fernández Fuertes

Received: 22 September 2021 Accepted: 20 February 2022 Published: 4 March 2022

Publisher's Note: MDPI stays neutral with regard to jurisdictional claims in published maps and institutional affiliations.

Copyright: (C) 2022 by the authors. Licensee MDPI, Basel, Switzerland. This article is an open access article distributed under the terms and conditions of the Creative Commons Attribution (CC BY) license (https:// creativecommons.org/licenses/by/ $4.0 /)$.

\begin{abstract}
Research on writing that focuses on what writers do when they compose shows that processes such as planning, transfer to writing and editing are recursive and affect the writing process of first and second language writers differently. To our knowledge, what has yet to be explored in research is the writing process of young bilingual students. The present study focused on the revisions and spelling errors made by 9-year-old bilingual students during a writing activity in their L2. Details about the writing process (e.g., revisions) were taken from statistics registered in the keystroke logging program ScriptLog and were analyzed both quantitatively and qualitatively. Results from the quantitative analysis show that the mean proportion of the students' revisions is relatively low compared to results in previous research. The qualitative analysis showed both surface and meaning changes; the latter were found at both the micro- and macrostructural levels. Bilingual students exhibit a creative writing process in which several meaning changes occur in a language (in this case Swedish) that they are particularly competent in. The spelling error analysis indicated that the bilingual students make the same type of spelling errors as monolingual students in their initial stages of learning to write.
\end{abstract}

Keywords: bilingual children; writing process; keystroke logging; revisions; spelling

\section{Introduction}

Writing a text is cognitively demanding for all writers and even more so for second language writers. Previous studies have found that second language writers spend more time finding the appropriate word or deciding on the form of the language compared to first language writers (Cumming 2001; Silva 1993). Novice or younger writers, meanwhile, will often spend time on revisions, concentrating on spelling or wording, and less time on structure and cohesion (Allal 2004; Becker 2006). Depending on the demands on working memory or the lack of diagnostic skills, revisions may not always lead to improvement (Odilia Breuer 2017).

One model from research on writing that focuses on what writers do when they compose a text is that by Hayes and Flower (1980), which has three main components: planning, transfer to writing and editing. These three processes are recursive and compete for cognitive capacity, meaning that the more automatized a particular process is, the less cognitive capacity it requires. Global revisions of a text and meaning changes might require a higher cognitive effort compared to revisions of errors at the surface level, e.g., spelling errors involving lower cognitive effort (Piolat et al. 2004).

In the digital writing process, students create the text while writing and processing it at a detailed level. Thus, the students manage both content and form simultaneously (Nordmark 2014). According to Nordmark (2014), this means that the planning of text content takes place more continuously while the text is emerging. This intertwining of the different phases in the process of writing on a computer was confirmed by Gnach et al. (2007) in a case study on the writing process of students in grade 4 . Other findings in research 
on writing show that students can reduce the number of errors they make if they use a computer for writing (Grejda and Hannafin 1992) while also improving the quality of their writing (Breese et al. 1996; Lam and Pennington 1995). These latter results were confirmed in a metastudy (Goldberg et al. 2003), which also showed that students who write using a computer tend to produce longer passages than students who write using paper and pencil, and that they made more changes.

The present study focused on the revisions ${ }^{1}$ and spelling errors made by 9 -year-old bilingual students in a writing activity on computers. All of the students but one were born in Sweden and had foreign-born parents who spoke another language than Swedish at home. As newborns, one language dominated; however, in early childhood, they heard and learned a second language at daycare or preschool and grew up in an early second language acquisition setting (De Houwer 2021). One of the students came to Sweden at the age of five and already had an established oral first language and learned Swedish as a second language (De Houwer 2021). It is of particular interest to explore the writing process of this category of students in light of today's increasingly multilingual classroom as many of these students must follow instructions in their second language, Swedish. However, how bilingual students use their languages during the writing process can vary as a result of several factors, such as in which of their languages they are most competent, especially within the context of school. Knowing about the revisions bilingual students make, and how they use their second language, is of great interest to teachers for the planning of their writing instruction, including the teaching of spelling rules. It has thus great didactic significance for teachers in Swedish as a second language.

The aim of this paper was to describe and analyze the writing process of early second language learners of Swedish with a focus on the revisions they make while writing a short text in Swedish using a computer. More specifically, the aim was to analyze their surface and meaning changes as well as remaining spelling errors in their final texts. The present study addresses the following research questions:

1. To what extent do the bilingual students revise their texts?

2. What types of revisions do the bilingual students make during the writing process?

3. How can their spelling errors in the final text be explained?

\section{Writing Processes and Revisions}

The theoretical framework for this study is the writing process model by Hayes and Flower (1980), which set out to allow for an understanding of writing performance and revisions from a cognitive perspective. Hayes and Flower were interested in the mental processes during writing, and their research participants were asked to think aloud while writing. The task environment, cognitive processes and the writer's long-term memory are the three basic components of their model, together with planning and transfer to writing ${ }^{2}$. In this study, we focused on revision during the writing process.

One way to investigate the writing process is to analyze a writer's activity using a keystroke logging program. One of several keystroke logging programs available that enable researchers to collect data during the writing process without interrupting the writer is ScriptLog (Strömqvist et al. 2006). Detailed information about the writer's activity during online writing is stored in a log file. The program registers the number of tokens ${ }^{3}$ in the final text and during the writing process, i.e., keystrokes in linear text ${ }^{4}$, as well as the total typing time, revisions, number and length of pauses, and changes and movements in the text. This information is not visible to the writers, who can work with the text as they usually would when writing on a computer.

Earlier research on revisions has focused on the type of revisions L1 and L2 writers make. In their research on the writing processes of high school students writing in L1 Swedish and L2 English, Lindgren et al. (2008) found that conceptual ${ }^{5}$ revisions were more frequent in the L1 processes of students, whereas a greater number of form revisions were found when students wrote in their second language. The researchers concluded 
that revisions depended more on students' linguistic experience than on their linguistic competence. In a study by Odilia Breuer (2017), German students of English philology wrote texts on different topics in their L1 (German) and their foreign language (English). At a broad level, the same revisions were made in both texts by the students, although analyses at a deep level showed differences related to students' linguistic competence. No influence of L1 was found in revisions in the texts written in English.

\subsection{Children's Writing Processes}

In a study on the association between the revisions made by third grade school children and their final written product, Von Koss Torkildsen et al. (2016) found that most children spontaneously made local (i.e., in the same place in the text) online revisions while writing, and few revised previously written texts. Children with good spelling skills made more online revisions than their peers. Thus, researchers concluded that the factor that influenced the writing process most was spelling, in that better spelling could be associated with more revisions and faster writing.

According to Chanquoy (2009), revision is a cognitively complex and costly process that aims to improve the quality of a text, and it can occur at any time during writing. Previous research on writing by hand has shown that younger children make relatively few revisions to their texts because they are busy transferring their thoughts into written language, while planning and revision skills develop later (Berninger et al. 1992; Berninger and Swanson 1994). According to Scardamalia and Bereiter (1987, p. 155), a typical elementary school manuscript may show no revisions at all but with certain types of instruction; however, children do begin to make revisions of some consequence. Allal (2004) found that students in grade 2 focused on the lexical aspects of spelling, while revisions made by students in grade 6 concerned the grammatical aspects of spelling, semantics and text organization. However, the degree to which units in a text are revised can be influenced by factors other than the writer's age and writing experience. For example, how much the writer knows about the theme in combination with their knowledge about language rules allows for more error detection and correction (Chanquoy 2009).

In a study on the writing process of grade 3 Finnish children in schools where Swedish is the language of instruction, which focused on revisions, Wengelin (2013) found that the monolingual Swedish-speaking children revised their texts more $\left(9 \%{ }^{6}\right)$ than the bilingual Swedish-Finnish children ${ }^{7}(4.5 \%)$. However, the Finnish children whose L2 was Swedish ${ }^{8}$ revised as much as $20 \%$ of the written characters in their text when writing in their $\mathrm{L}^{9}$. The revisions of the latter group were then classified based on Faigley and Witte's (1984) Revision Taxonomy, according to which revisions are divided into surface changes, including grammar, spelling and keyboard errors, on the one hand, and meaning, on the other. The meaning revisions change the meaning of the text. The results of Wengelin's study showed that the children's revisions were primarily local changes of a single letter and involved both spelling changes and keyboard errors, whereas conceptual changes did not occur at all. Interestingly, morphosyntactical revisions were not found in the children's writing process. Wengelin (2013) concluded that a large number of surface changes can be explained, in part, by the writing task (narrations elicited by a series of pictures), and such a task does not generate major meaning changes.

In a study by Asker-Àrnason et al. (2008), students aged 8-12 were asked to write a story. The authors suggested that pausing may have been the result of revisions, such as spelling, and inexperience using a keyboard (i.e., finding the right key), since all participants were young and were most likely inexperienced writers.

The writing process of bilingual students was studied by Lindström and Zetterholm (2019) and Zetterholm (2019) through an analysis of texts written by students in grades 2 and 3 (aged 8-10) with a focus on writing fluency, keyboard activity, pauses and length of the final text. The results showed great individual variation between students in terms of fluency, length of pauses and number of characters both during the writing process and in the final texts. However, in the study by Lindström and Zetterholm (2019) with students in 
grade 2, a correlation was found between fluency measured in terms of median transition time $^{10}$, less pause time and the number of words in the final texts. The same results were found in the study with students in grade 3 at the group level (Zetterholm 2019). A difference between the two studies was the higher number of characters both in the writing process and in the final texts of grade 3 participants. This may be due to age and the fact that they had more experience writing texts on computers.

\subsection{Ivanič's Discourses: Teaching the Writing Process}

Studies on the writing process can relate to both the cognitive and the practical processes. The focus for teaching should be on practical processes when the aim is to improve the product. Ivanič (2004) introduced a framework for writing pedagogy including the learning, teaching and assessment of writing. She also presented six discourses of writing, of which four are relevant from a didactic perspective for the results of this study, namely, the skills, the creativity, the process and the genre discourses. The skills discourse focuses on the product and on knowledge of the relationship between sound and symbol and syntactic patterns. Spelling patterns and punctuation, as well as sentence structure, must be taught explicitly. In the creativity discourse, the authors' creativity and engagement when writing are the focus. When learning to write, it is important that the novice writer practices as much as possible. Reading fiction can stimulate writers, as can the opportunity to write about their own experiences or interests. The process discourse includes both the mental process of composing and its practical realization. The genre discourse, meanwhile, is about writing different types of texts for different purposes in specific contexts. Ivanič identified two more discourses: the social practices discourse and the sociopolitical discourse. However, we found these to be less relevant for this study and as such did not include them in our analysis.

\subsection{Learning to Write in a Second Language}

Many children around the world grow up speaking more than one language or varieties of languages on a daily basis. Children who need to communicate in more than one language before the age of 12 are referred to as bilingual children regardless of the extent to which they use the languages (De Houwer 2021, p. 3). They need to learn and speak another language in preschool and school than the one spoken at home. Second-generation immigrants (i.e., children born in Sweden) who grow up attending Swedish preschool often learn both Swedish and the language spoken at home more or less simultaneously. According to the definition by De Houwer (2021), they are early second language learners.

Depending on the quality and quantity of input and output, which of the languages they define as their strongest may vary over time. Skutnabb-Kangas (1981) suggested three definitions of an L1: the language children learn first, the language they identify themselves with and the language they most frequently use or master to a higher level. Different studies have shown that multilingual children who learn to write in and read more than one language at the same time become biliterate, are aware of the differences and similarities between languages and know how to use this knowledge in different contexts (Kenner 2004; Kenner et al. 2004). Learning to read and write in different languages simultaneously requires specific cognitive skills and contributes to a high metalinguistic awareness and level of competence (Bialystok et al. 2009). Children who learn how to use the different writing systems in various contexts also gain an awareness of the relationship between pronunciation and graphemes in different languages. The use of different languages in life and communication also strengthens the identity of multilingual children. This was shown in what are called identity texts written by students in grade 5 (Wedin 2021). Creative writing and the opportunity to choose the language for writing inspired the students to express multiple identities in texts about themselves.

Young multilingual students sometimes transfer phonological, phonotactic and orthographic rules from their L1 when learning a second or foreign language. In the early stages of learning to write in Swedish, bilingual students made the same types of spelling errors 
as monolingual Swedish children (Zetterholm 2017). However, there are other spelling errors that can be explained by their L1. A study by Andersson (1981) showed that students transferred spelling rules to their second language according to the contrast between speech sounds, phonemes and the phonotactic structure in their L1 and Swedish. Learners with Finnish as their L1 changed voiced plosives to unvoiced plosives, which is in line with the set of phonemes in Finnish, and learners with Turkish as their L1 used epenthesis when writing words with consonant clusters in Swedish, which reflects the phonotactic structure in their L1. Transfer from students' L1 to their L2 was found in a study involving multilingual students in grade 2 (Zetterholm 2017). Several Somali speakers were confused when writing words that included $\langle\mathrm{v}\rangle$ and $\langle\mathrm{f}\rangle$, probably as a result of the differences in phonemes in Swedish and Somali, since Somali has the phoneme /f/ but not /v/, whereas Swedish has both. The word löv (leaf) was spelled $<$ löf $>$ or $<$ löv $>$ in the same text written by one of the students.

\subsection{The Relationship between Swedish Orthography and Pronunciation}

There is no clear one-to-one correlation between orthography, graphemes and the pronunciation of phonemes in Swedish. The Swedish phonotax allows for a short vowel and a long consonant (VC:) or a long vowel and a short consonant $(\mathrm{V}: \mathrm{C})$ in stressed syllables (Garlén 1988). An orthographic cue is the spelling with double letters for long consonants, e.g., fin (nice) / fi:n/ and finn (found) / fin:/. However, there are some exceptions, mostly depending on the morphology. The spelling of words can be based on the phonology in relation to pronunciation or on morphology and the historical relationship between words.

When Swedish children start learning how to spell, they commonly make similar spelling mistakes. Nauclér (1989) found double letters for a long consonant, epenthesis, omissions, changes and metathesis to be the most common errors. Such errors may result from a lack of vocabulary, spelling rules and phonological awareness or from the fact that some graphemes are rather similar, such as $\langle\mathrm{b}\rangle,\langle\mathrm{d}\rangle,\langle\mathrm{p}\rangle,\langle\mathrm{a}\rangle,\langle\ddot{\mathrm{a}}\rangle$ and $\langle\ddot{\mathrm{o}}\rangle$, or the fact that we make mistakes when writing on keyboards because the letters are positioned close to each other. Some errors are phonologically accepted: for example, bärj ${ }^{* 11}$ instead of the correct berg [berj] (mountain) or sykel* instead of cykel [syk:cl] (bicycle).

The following are examples related to the differences between orthography and pronunciation that may be hard for beginners-both first and second language learners of Swedish—to learn. The phoneme $/ \mathrm{j} /$ can be spelled $\langle\mathrm{j}\rangle|\langle\mathrm{hj}\rangle|\langle\mathrm{dj}\rangle /\langle\mathrm{lj}\rangle /\langle\mathrm{gj}\rangle /\langle\mathrm{g}\rangle$ : for example, jul/hjul [ju:l/ju:l] (Christmas/wheel), djur [ju:r] (animal), ljög [jø:g] (lied), gjorde [ju:dє] (did) and hjürna/gärna [jæ:na/jæ:na] (brain/willingly). The phoneme / f/ can be spelled $<$ stj $>/<$ sk $>/<$ skj $>/<$ sj $>$ : for example, stjärna [f̣æ:na] (star), sked [fje:d] (spoon), skjorta [fut:a] (shirt) and själv [fjel:v] (self). The phoneme / $/$ / can also be spelled in different ways: for example, kärna [cæ:na] (kernel), and kjol [cu:l] (skirt). The letter <o > can be pronounced as both a long and a short vowel and can be pronounced /su:l/ in sol (sun), /luts:/ as in lots (pilot) and also as a more open vowel, as in son /so:n/ (son) or som /som:/ (as). The word pairs gott/gått/got:/ and sett/sätt/set:/ are pronounced the same, and their spelling is thus often confusing for learners.

\section{Material and Method}

In this section, we present the material and the method used in this study, which is followed by a brief presentation of the assessment material in reading and writing development according to which the study participants are classified. The section concludes with a brief description of the theoretical model on which the qualitative analyses are based.

\subsection{Material}

The material was collected as part of a large-scale, three-year research project ${ }^{12}$ that focused on a school in Sweden for students aged 6 to 12 (grades 1-6). The school is located in a small city in a district where most adult residents are not Swedish-born or do not have Swedish as their L1. However, many of the children were born in Sweden and learned 
Swedish in early childhood. More than $90 \%$ of the students at this school are second language learners of Swedish according to information provided by the school's head teacher. The research project aimed to look at ways to teach bi- and multilingual students, to analyze the teaching in all subjects and to help teachers to develop professionally with a specific focus on the identity and language of bi- and multilingual students. Researchers and teachers worked together both inside and outside the classroom, and the researchers became members of the school staff and were therefore not strangers to either employees or students.

For the present study, grade 2 students were asked to write a text: it could be on any topic. If students asked for advice or suggestions, they were told either to write about what they did in their recent autumn break or their interests in general, or to write a fairy tale. In total, 17 students wrote two short texts on two separate occasions (Lindström and Zetterholm 2019). For this paper, texts by 7 students (thus 14 short texts in total) were selected that were 180 tokens or longer. The texts were chosen based on log files from ScriptLog concerning keystrokes in linear texts as well as the number of tokens in final texts. All participants were bilingual in the sense that at least one of their caregivers had another L1 than Swedish, they all spoke another language than Swedish at home with their parents and they were early second language learners. All the participants were born in Sweden, except for one, who immigrated to Sweden at the age of five. No language tests, oral or written, were conducted in either language of the students, and they were only asked to write in Swedish for this study. As such, it is hard to ascertain which of the languages is their strongest.

\subsection{National Assessment Material in Reading and Writing Development}

The Swedish National Agency for Education (2019) has established national assessment material in reading and writing development for grades 1-3 in elementary school that is based on the syllabus for Swedish and the syllabus for Swedish as a second language, and the knowledge requirements for these subjects in grade 3 . The purpose is to enable teachers to follow students' reading and writing development and to support an equivalent assessment of students' knowledge in their early school years. The material is based on current research and includes observation points to screen students' writing ability according to three different levels, i.e., A to C. A benchmark in the assessment material is that a student in grade 1 should achieve level A, which is the lowest level, by the end of grade 1. Similarly, a student in grade 2 should achieve level B (the middle level) by the end of grade 2 , and a student in grade 3 should achieve level $C$ by the end of grade 3 . The various criteria in the national assessment material are, for example, the use of capital letters, writing communicative texts (the aim of the writing), spelling common/frequent words and punctuation: these are the same for both the subjects of Swedish and Swedish as a second language. At level B, students should be able to write a short text that is simple in content.

To ensure inter-rater reliability, the final 14 texts used in this study were assessed separately by the authors using the national assessment material in order to establish whether or not they corresponded to the expected levels for grade 2. Both raters agreed that all written texts met all or a major part of the criteria for level B, which corresponds to grade 2 in elementary school.

\subsection{Method}

ScriptLog was installed on some of the computers used by the seven grade 2 students. They were familiar with the computers and knew how to use the keyboard. They were asked to write a text, for about $20 \mathrm{~min}$, on any topic as part of the ongoing research project at their school. The teacher and one of the researchers were present in the classroom for the whole lesson. The students were not allowed to use either an Internet program or a spelling program while writing, and the two adults did not answer any spelling-related 
questions. Two weeks later, they were asked to write a new text in order to collect more material and to be sure that everyone who wanted to write had the opportunity to do so.

\subsection{Ethical Considerations}

Everybody at the school-head teachers, teachers, mother tongue teachers and librarians as well as students and their parents-were well informed about the ongoing research project at the school and provided their written consent for the research. All researchers involved in the project were permitted to be present in every classroom at any time to collect different types of data, and the data collection was discussed with the teacher concerned.

\subsection{Data Analyses}

The present study is descriptive and has an inductive approach, and it uses data collected from the ScriptLog program concerning multilingual students' revisions during writing. All the logging files and final texts were downloaded to the researchers' computers, and the data were analyzed both quantitatively and qualitatively. The quantitative data, such as the total number of revisions, were counted by the log files from ScriptLog as well as the number of words in the final texts, total number of revisions, number of revisions containing one or more character and the proportion in percent of revisions in relation to the number of characters in the final text. In the qualitative part of the analyses, the revisions were analyzed based on Faigley and Witte's (1984) taxonomy of revisions (Table 1).

Table 1. Faigley and Witte's (1984) taxonomy of revisions.

\begin{tabular}{cccc}
\hline \multicolumn{2}{c}{ Surface Changes } & \multicolumn{2}{c}{ Meaning Changes } \\
\hline Formal & $\begin{array}{c}\text { Meaning-Preserving } \\
\text { Changes }\end{array}$ & $\begin{array}{c}\text { Microstructure } \\
\text { Changes }\end{array}$ & $\begin{array}{c}\text { Macrostructure } \\
\text { Changes }\end{array}$ \\
\hline Spelling & Additions & Additions & Additions \\
Tense, number, & Deletions & Deletions & Deletions \\
modality & Substitutions & Substitutions & Substitutions \\
Punctuation & Permutations & Permutations & Permutations \\
Abbreviation & Distributions & Distributions & Distributions \\
Format & Consolidations & Consolidations & Consolidations \\
\hline
\end{tabular}

According to Faigley and Witte's (1984, p. 97) system, the distinction between the left (surface changes) and the right (meaning changes) column can be explained by whether or not new information is brought to the text or whether old information is removed in such a way that it cannot be recovered through inference. Most of the categories were used in the current analysis, whereas the permutations, distributions and consolidations were less relevant as any such examples did not occur. In addition, we included keystroke errors in the category of surface changes. We identified errors that can be explained by keystroke errors (the keys on the keyboard are adjacent), although these errors are sometimes difficult to identify as they may also be considered to be spelling errors (cf. Damerau 1964). However, we found it important to try to distinguish them from the latter category (i.e., spelling errors); saying that, in ambiguous cases, we discuss this classification in the analysis.

Moreover, the length of each change needs to be addressed. Since the texts in the present study are relatively short, we used the following four classes originating from Bridwell's (1980) system for classifications of revision lengths: graphic changes, lexical changes, phrasal changes and clausal changes. This system originally contained two additional categories (sentence changes and multisentence changes); however, we did not find these to be relevant for our analysis.

The spelling analysis in the final texts was conducted in two steps. The first step was a categorization of spelling errors following some of the sub-categories presented by Bestgen and Granger (2011) ${ }^{13}$, supplemented with one category related to young Swedish children's most common spelling errors (Nauclér 1989). The second step was a comparison of spelling errors according to the different categories. 


\section{Results}

In this section, results from the analyses are presented first from the quantitative analysis consisting of different measures of text lengths, supplemented by measures of revisions made during the two writing occasions by the bilingual students, all of them anonymous. These analyses show to what extent the bilingual students revise their texts. The quantitative findings consist of results from two writing occasions, as presented in Tables 2 and 3 below, and are followed by the presentation of the results of the qualitative analysis. The latter analyses show what types of revisions the bilingual students make in their texts. Finally, an analysis of the most common spelling errors in the students' final texts is presented.

Table 2. Overview of text length and absolute number and proportion of revisions in students' final texts from the first writing occasion.

\begin{tabular}{ccccc}
\hline Informants & $\begin{array}{c}\text { No. of } \\
\text { Tokens }\end{array}$ & $\begin{array}{c}\text { Total No. of } \\
\text { Rev. }\end{array}$ & $\begin{array}{c}\text { No. of Rev. }>\mathbf{1} \\
\text { Token }\end{array}$ & $\begin{array}{c}\text { Proportion of } \\
\text { Rev. }\end{array}$ \\
\hline Aisha & 429 & 31 & 9 & $7 \%$ \\
Blanka & 221 & 15 & 9 & $7 \%$ \\
Eman & 209 & 8 & 2 & $4 \%$ \\
Luke & 284 & 30 & 6 & $11 \%$ \\
John & 193 & 23 & 10 & $12 \%$ \\
Miriam & 285 & 22 & 6 & $8 \%$ \\
Ermin & 291 & 16 & 7 & $5 \%$ \\
\hline Mean & 279 & 21 & 7 & $8 \%$ \\
Sdv. & & 11 & 1 & $1 \%$ \\
\hline${ }^{*}$ rev. = revisions. & & & &
\end{tabular}

Table 3. Overview of text length and absolute number and proportion of revisions in students' final texts from the second writing occasion.

\begin{tabular}{ccccc}
\hline Informants & $\begin{array}{c}\text { No. of } \\
\text { Tokens }\end{array}$ & $\begin{array}{c}\text { Total } \\
\text { No. } \text { Rev. }\end{array}$ & $\begin{array}{c}\text { No. of Rev. }>\mathbf{1} \\
\text { Token }\end{array}$ & $\begin{array}{c}\text { Proportion of } \\
\text { Rev. }\end{array}$ \\
\hline Aisha & 317 & 4 & 0 & $1 \%$ \\
Blanka & 438 & 24 & 9 & $6 \%$ \\
Eman & 200 & 23 & 5 & $12 \%$ \\
Luke & 272 & 22 & 6 & $8 \%$ \\
John & 186 & 7 & 3 & $5 \%$ \\
Miriam & 406 & 19 & 6 & $10 \%$ \\
Ermin & 335 & 34 & 8 & $6 \%$ \\
\hline Mean & 257 & 19 & 5 & $6 \%$ \\
Sdv. & 21 & 6 & \\
\hline
\end{tabular}

* rev. = revisions.

\subsection{Quantitative Analysis}

\subsubsection{Revisions-First Writing Occasion}

Table 2 shows differences in text length and number of revisions. The measure of text length used is: "No. of tokens", which shows the length of the final text. It can be deduced that there are differences between students in terms of both text length and number of revisions. The relative number of revisions is given in the column to the right corresponding to the number of revisions divided by the number of tokens in the final texts.

It appears that the mean percentage of revisions for the group is $8 \%$, which can be compared with the results of the revisions of bilingual children in grade 3 in Wengelin (2013), with $4.5 \%$, whereas the L2 children in her study revised as much as $20 \%$ of the written characters. The lengths of the final texts vary within the group, but it is important to remember that the writing process can be longer in terms of the number of tokens than the number of words in the final text and might include several revisions of the same character or letter. 
The table also shows that a majority of the revisions were to one token, which affirms the results in Wengelin's (2013) study. At an individual level, two children, Luke (11\%) and John $(12 \%)$, had a particularly high proportion of revisions on this writing occasion.

\subsubsection{Revisions-Second Writing Occasion}

The summary of the data from the second writing occasion is presented in Table 3 above. This writing occasion took place about one month after the first occasion, so there was not expected to be any development in writing ability. As mentioned above, the writing task was largely identical. It appears that the proportion of revisions is somewhat lower at the group level $(6 \%)$ than on the first writing occasion $(8 \%)$. A further point is that, at the group level, the text length of the final text is about the same as on the first writing occasion.

At an individual level, it is interesting to note that the proportion of revisions students make varies between the two writing occasions. For instance, Luke and John, who had a higher proportion of revisions during the first writing occasion, lowered this proportion during the second writing occasion, whereas the opposite was the case with Eman and Ermin. Eman wrote texts with approximately the same number of tokens during both writing occasions. Thus, no conclusions regarding development when it comes to the proportion of revisions can be deduced at the individual level from these data.

\subsection{Qualitative Analyses of Informants' Revisions}

In this section, the students' revisions are analyzed qualitatively. As already noted above, a major proportion of the revisions made by the students involved only one character. All changes were analyzed according to Faigley and Witte's (1984) taxonomy of revisions presented in Table 1. Surface changes are presented first, and thereafter meaning changes. The revisions are shown with an arrow $(->)$ in the running text. Some sequences are analyzed in more detail and are therefore presented as numbered examples below.

\subsubsection{Aisha}

There are several examples of graphic changes that could be classified as formal surface changes, such as keyboard errors: these are mosr $\rightarrow$ moster, and skam $\rightarrow$ ska, where an adjacent key is typed, or a key is typed twice: ätt $->$ äta. Changes such as kvå $->k v a ̈ l l, l a ̊$ $\rightarrow$ läa $\rightarrow$ läs $a$ and $f \ddot{a} \rightarrow>$ för can be explained as a type of uncertainty about the diacritics of the Swedish vowels <å ä ö> or as keyboard errors. In the writing process, there are also several examples of changes back to the same word or letter. This may relate to her planning and her cognitive process. The following examples could be classified as keyboard errors: skRiVitt [written] with two capitals is changed to skrivit without capitals, and the letter combination blr is changed to blev [was]. The letters $r$ and $e$ are adjacent keys on the keyboard, which could explain this error.

The following sequence involves a more substantial change where part of the meaning of the narration is changed:

(1) sen ska gå till magdonlas [Then will go to magdonlas] is changed to

(2) sen ska jag till min pappas fru [Then I will go to my dad's wife]

This is considered to be a microstructural change, which is phrasal since the narration is still about where to go with a change that concerns the place to go to: i.e., from magdonlas (McDonald's) to min pappas fru. It is still a narration about what Aisha will do, but the content is changed in terms of the goal of the activity that she tries to explain. Therefore, this could be classified as a change in meaning, in this case at the microstructural level.

\subsubsection{Blanka}

In both of Blanka's texts, formal surface changes occur, such as spelling or keyboard errors: Näe -> när and del $->$ det, as well as iett $->i$ ett, a distribution due to an incorrect consolidation, and efter 5 -> efter, where a typing error is erased. Some of her changes are to the same unit: for example, Hösten [Autumn] -> Hösten, and höstlovet [autumn break] $->$ höstlovet. This phenomenon is quite common in other texts and seems to be a sign 
of uncertainty or a lack of planning. In Blanka's second text, there are also a couple of examples of meaning-preserving surface changes in terms of substitutions such as efter [after], which is changed to sen [then], and the following sequence that includes two changes:

(3) hon [she] is changed to Pr, which is then changed to sen levde [then lived]

The first change from hon to $\operatorname{Pr}$ (probably the beginning of Princess) is lexical and consists of a meaning-preserving surface change, while the second revision sen levde is phrasal and changes the meaning and is therefore considered to be a microstructural meaning change. There are a couple of examples of revisions that could be classified as formal changes at a syntactical level, such as Hösten [Autumn] -> På hösten [In the autumn]. This could also be seen as a meaning change at the microstructural level since it changes the beginning of the sentence. Another example of a meaning change at the microstructural level is the following beginning of a sentence:

(4) När det... [When it...] is changed to På hösten går... [In the autumn goes...]

Additionally, in Blanka's second text, the following microstructural meaning changes in the form of substitutions that can be found:

(5) hon heter [her name is] is changed to hon hade slavar [she had slaves]

(6) dödre o hon prinsesan [she killed the princess] is changed to sa häxan till prinsesan [said the witch to the princess]

In example (5), Blanka talks about a witch and starts to introduce the name of this character. Then, she changes the content and starts to provide other information about this character. The same phenomenon happens in example (6), where the action changes from the killing of the princess to something that is simply said to the princess. At a macrolevel, the content is the same because the narration still concerns a witch and a princess, but changes occur at a microlevel.

\subsubsection{Eman}

Eman's texts include some examples of formal surface changes such as spelling: for example, mama $\rightarrow$ mammam, xbox $\rightarrow$ exboks and $x \rightarrow$ exbox. His topic is computer games, and in the following sequence, a lexical change occurs, which could be due to uncertainty about the spelling:

(7) $x b o x$ is changed to exboks, which is changed to pljet [probably "play"], which is changed to dataspel [computer games]

Thus, example (7) is classified as a meaning-preserving change of the surface structure in terms of a substitution. In another sequence, Eman talks about a book about outer space that he writes in. He changes the content of the sentence: skriver om $r$ [writing about $r$ ] is changed to skriver $i$ den [writing in it]. This change is classified as a meaning change. In Eman's second text, there are examples of spelling changes, i.e., formal surface changes, such as the word *kerig, which is the incorrect spelling and changed to the correct spelling krig [war]. This might be a keyboard error or relate to the pronunciation of $/ \mathrm{k} ə r i \mathrm{~g} /$. In addition to this, there are some formal changes in terms of punctuation, where a comma is changed to a period.

\subsubsection{Luke}

Most of Luke's revisions consist of formal surface changes such as changes from small letters to capital letters and vice versa ( $m i->$ Mit höstlov, Fot $\rightarrow$ fot, EFTE $>$ Efter). There are also examples of lexical microstructural meaning changes, such as when an abbreviation $(p s)$ is changed to the whole word (Playstation) and when the word fotbollskor [football shoes] is changed to träningsskor [trainers], or the phrase kul I he... [fun in the he...] is changed to jetekul i låvet [great fun in the break]. Here, *låvet is a phonologically accepted spelling of break; the correct spelling is lovet, but it is pronounced /lo:vet/. 


\subsubsection{John}

John makes some formal surface changes to spelling (bibloseket -> bibloteket [the library], mama -> mamma [mother], höstlovd -> höstlovet [autumn break]). In the following sequence, he changes from the correct to an incorrect spelling and then to the correct spelling again:

(8) cyklar [biking] is changed to cklar, which is changed again to cyklar

This indicates a spelling uncertainty. There are also several changes that could be classified as keyboard errors where capital letters are used at the beginning of a sentence instead of small letters (JAG [I] -> Jag) and vice versa ( $h$-> Hösten [The autumn]).

\subsubsection{Miriam}

Miriam makes some formal surface changes to spelling (renar $->$ regnar) (De $->D E T$

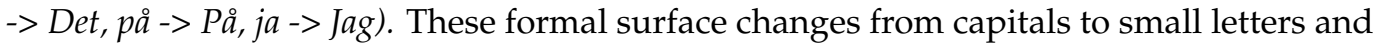
vice versa could also be keyboard errors. Other than that, she makes some microstructural meaning changes in terms of substitutions. In the following sequences, she revises one or several units, which results in a change in meaning:

(9) hösten [the autumn] is changed to när jag går [when I go]

(10) när jag går på hösten [when I go in the autumn] is changed to på hösten är det kallt [in the autumn it is cold]

(11) de [they] is changed to ok, which is then changed to och [and]

(12) På hösten [In the autumn] is changed to Jag gilar inte [I don't like]

In example (11) above, the word de is first changed to the word ok (and), which is incorrectly spelled, which is then changed again to och (and), this time correctly spelled. In the second text, Miriam makes a more substantial change that could be classified as a macrostructural meaning change in terms of substitutions. In the first sentence of her written production, she changes the content of the story completely, which, in turn, changes the meaning entirely:

(13) Vi lekta alala var häxor det var gete kul jag och zahra [We played everyone was witches it was great fun me and Zahra] is changed to Det var en gong en häxa hon var elak mot alla barn [Once upon a time there was a witch she was mean to all children].

The spelling of "great fun" ("gete kul) is one example that demonstrates the difficulty about how to spell the phoneme / $\mathrm{j} /$. In Swedish, "great fun" (two words) is written as a compound word, jättekul. "Once upon a time" (en gong) is spelled en gång in Swedish, and this is an incorrect spelling of the phoneme $/ \mathrm{o} /$. As the sequence above is changed completely, i.e., even at a phrasal or sentence level, we classify it as a macrostructural change. The story is still about witches but has a different overall meaning. Here, the student has replanned the story completely.

\subsubsection{Ermin}

Ermin's texts also include some formal surface changes that concern spelling or keyboard errors, such as $b b$, which is changed to bara. Another spelling change is from systa to syster [sister]. The second text also contains what can be classified as formal surface changes in the form of syntactic additions: for example,

(14) han *akk [he goes] is changed to flygplanen [the airplanes], which is then changed to *ha skulle åka till [he should go to]

(15) han va rädd hans familj [he was afraid his family] is changed to han va rädd för sin familj [he was afraid of his family]

Other formal surface changes that could be considered as either spelling changes or keyboard errors are the following: flygpa -> flygplanen, hand $->$ han, si -> sälv, og -> och. The word *älv is one example of difficulty with the different spellings of the phoneme / $\mathrm{g} /$. A major proportion of Ermin's revisions are microstructural meaning changes in terms of substitutions or additions. Here are some examples:

(16) han va 61 år (he was 61 years old) is changed to han va 16 år (he was 16 years old)

(17) bara slog honom (just hit him) is changed to bara slog jonatan (just hit jonatan)

(18) inte (not) is changed to han slog inte mer (he did not hit anymore) 
(19) *Filde jonatan $\ddot{a}$ (i.e., celebrating jonatan) is changed to *filde jonatan kalas (i.e., celebrating jonatan party)

(20) han filde år (his birthday) is changed to han filde 11 år (his 11th birthday)

Example (16) above, concerning the age of a person, could also be a keyboard error. In that case, it is a formal surface change. Example 19 makes no sense in Swedish and is then corrected to example 20, which is correct.

\subsection{Summary of Revisions}

The quantitative analysis showed that the mean proportion of revisions for the group on both writing occasions is relatively low when compared with the results of L2 third grade children in previous research by Wengelin (2013), but slightly higher than the bilingual children in the same study. This could indicate that the children in the present study are used to writing in Swedish and also that they have a certain amount of computer experience. A major proportion of the revisions relate to a single character, which also accords with the results in the Wengelin (2013) study.

We noted that most of the revisions are surface changes, such as capitalization or keyboard errors. Some of the surface changes could concern spelling-for instance, difficulties with the diacritics of Swedish vowels. However, the analysis of revisions showed no spelling corrections that could clearly be explained by the relationship between pronunciation and Swedish spelling rules. Other surface changes that occur relate to punctuation and include changes from a comma to a period, and vice versa, whereas morphosyntactical changes occur only to a very small extent. Further, the writing process of these bilingual students includes meaning-preserving changes in the form of substitutions when a word or the beginning of a word is changed to another unit that preserves the meaning. This phenomenon could be explained by the fact that the students' changes to a word correspond to their linguistic competence. Surprisingly, the analyses of the students' writing process also show that many changes in the form of substitutions can be considered microstructural, meaning that new information is brought to the text that changes the meaning of the written production. These types of changes are less common among more novice writers and writers writing in their second language (Becker 2006; Wengelin 2013). Moreover, previous research has shown that younger children make very few revisions to their texts because they are busy transferring their thoughts into written language (Berninger et al. 1992; Berninger and Swanson 1994; Scardamalia and Bereiter 1987). For their age, the students in this study make, relatively speaking, a large number of revisions to their texts, both formal and meaning changing, at both the micro- and macrostructural levels, and as such, we can conclude that they have developed certain planning and revision skills. Because the theme of the writing task can also influence the degree of revised units in the text (Chanquoy 2009), we can deduce that the free form of the writing task on these two writing occasions might have influenced students' propensity to revise their texts. They were free to change their stories based on their ability to articulate themselves. This phenomenon could be linked to Ivanič's (2004) creativity discourse, where the revisions are part of the author's creativity and engagement when writing.

\subsection{Spelling Errors in Final Texts}

For this study, the spelling errors found in the final texts were categorized according to what are known to be difficult and common spelling errors among Swedish children in their initial stages of learning how to write (Nauclér 1989). The categories, and the codes, follow some of the sub-categories presented by Bestgen and Granger (2011). We added a new category - spelling errors related to the phonemes / $/$ / and /6/. Examples (see Table 4) were taken from the students' final texts. 
Table 4. List of categories of spelling errors occurring in the final texts.

\begin{tabular}{|c|c|c|}
\hline Code & Description & Example \\
\hline $0 X$ & Omission of a letter & $\begin{array}{l}\text { faste/faster (aunt) } \\
\text { sprag/sprang (run) } \\
\text { vrje/varje (every) }\end{array}$ \\
\hline $\mathrm{X} 0$ & Addition of a letter & $\begin{array}{l}\text { rengnar/regnar (it's raining) } \\
\text { nyja/nya (new) } \\
\text { feredag/fredag (Friday) }\end{array}$ \\
\hline Doub12 & $\begin{array}{l}\text { Single letter instead of a } \\
\text { double letter }\end{array}$ & $\begin{array}{l}\text { kalt/kallt (cold) } \\
\text { böker/böcker (books) } \\
\text { afären/affären (the shop) }\end{array}$ \\
\hline$X Y$ & Substitution of one letter & $\begin{array}{l}\text { go/gå (walk) } \\
\text { skremde/skrämde (scared) } \\
\text { monga/många (many) }\end{array}$ \\
\hline SplitW & Word segmentation error & $\begin{array}{l}\text { höst lovet/höstlovet (the autumn break) } \\
\text { engång/en gång (once) } \\
\text { data spel/dataspel (computer game) }\end{array}$ \\
\hline$X Z$ & Substitution for $/ \mathrm{g} /$ or $/ \mathrm{c} /$ & $\begin{array}{l}\text { söpa/köpa (buy) } \\
\text { sälv/själv (self) } \\
\text { suvar/tjuvar (thieves) }\end{array}$ \\
\hline Many & $\begin{array}{l}\text { Two or more errors of the } \\
\text { same type or of different types }\end{array}$ & $\begin{array}{l}\text { simm halen/simhallen (the } \\
\text { swimming pool) } \\
\text { legre/längre (longer) } \\
\text { jurd/ljud (sound) }\end{array}$ \\
\hline
\end{tabular}

After the categorization of spelling errors, the next step was to compare the frequency of spelling errors by category. See Figure 1.

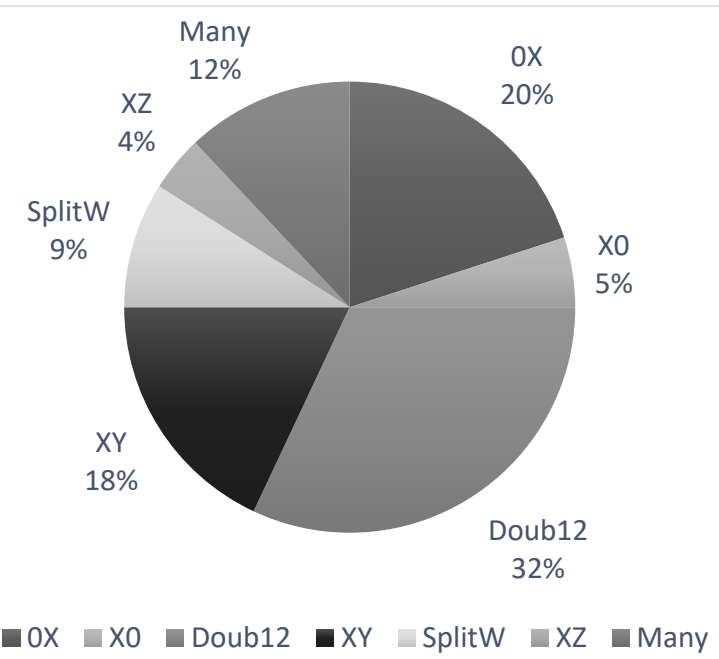

Figure 1. Frequency of spelling error categories.

It is obvious that spelling without double consonant letters, for the pronunciation of a long consonant, is the most common spelling error. This is in line with the results of studies on how Swedish children acquire knowledge in reading and writing (Nauclér 1989). No spelling errors with a double letter instead of a single letter were found in the texts.

Some spelling errors are phonologically acceptable when the orthography is close to the phonology and the pronunciation. These are found in the category 0X (omission of a letter) in words with "silent letters", e.g., tidning [ti:nIg] (newspaper) and var [va:] (was). Another example of phonologically acceptable spelling is the use of <å instead of 
$<0>$ in the Swedish word lov (holiday), pronounced /lo:v/. However, it is obvious that it is difficult for the students to know if the word is spelled with an $<0>$ or $<a ̊$ when it is pronounced /o:/ or / $/$. The most common mistake is the use of the letter $<0>$ instead of <å in the short phrase en gång (once upon a time) pronounced / हngoy:/ and spelled *engong, and the words många (many) pronounced /mon:a/ and spelled *monga, and månad (month) pronounced / mo:nad/ and spelled *monad.

The spelling of the speech sounds / $\varepsilon$ : and / $\varepsilon /$ can be confusing in Swedish, especially for beginners, both children and second language learners, since they can be spelled with an $\langle\mathrm{e}>$ or $<\mathrm{a}>$. In the texts, we found that $<\mathrm{e}>$ was used more frequently than $<\ddot{a}>$ in spelling errors: for example, skrämde (frightened) spelled *skremde, rädda (scared) spelled *reda (also missing double letters $<\mathrm{d}>$ ) and läsk (soda) spelled *lesk.

There are a few spelling errors that occur with compound words that should be written as one word in Swedish: for example, höstlovet (autumn break)/høstlo:vet/(höst + lovet). Most of these are found in the category "Many" since there is more than one error in the word: for example, *simm halen/simhallen (the swimming pool).

The Swedish postalveolar and alveolo-palatal fricatives / $\mathrm{g} /$ and $/ 6 /$ are often difficult to spell, possibly because there is great variation in terms of orthography. There are only four different words in all texts that contain these fricatives. As can be seen in Table 4, the fricatives are spelled in different ways in standard Swedish, and here, they are all replaced with an $<$ s $>$.

\section{Discussion}

The results of this study show that the students, despite being young and relatively inexperienced writers, made a great deal of changes during their writing process. This indicates that they have developed their writing and that they do not focus merely on transferring their thoughts into writing (Berninger et al. 1992; Berninger and Swanson 1994; Hayes and Flower 1980; Scardamalia and Bereiter 1987).

A major proportion of the revisions relate to only one single character in the texts, which confirms earlier research on revisions (Wengelin 2013). As there are both intra- and interindividual differences between the two writing occasions, no clear pattern is shown concerning the propensity of individuals to revise their texts. At an individual level, there seem to be several factors that influence the number of revisions made as well as the degree of revised units (Chanquoy 2009).

Our analyses show that participants made both surface and meaning changes, as defined in the taxonomy of revisions by Faigley and Witte (1984). Most changes were surface changes, such as formal and meaning-preserving changes. These include punctuation, capitalization and keyboard errors as well as a few spelling changes.

When it comes to meaning changes, they were often microstructural in terms of substitutions. There was only one revision at the macrostructural meaning level. This was when Miriam made a substitution and changed the content of her story. The relatively high number of meaning changes in this study is surprising as the bilingual students can be considered quite novice writers. This type of change is more associated with advanced and experienced writers and also with writers writing in their L1. This result may be explained both by the openness of the writing task in this study and also probably by the fact that the strongest language of the students in the present study is Swedish within the context of school.

The participants are relatively novice writers, and the results relating to their revisions, especially wording, are in accordance with Allal (2004). Further, it is to be expected that most revisions are surface changes (Faigley and Witte 1984), something common among novice writers as well as writers writing in a second or foreign language (Becker 2006). These early second language learners of Swedish seem to make very few revisions related to spelling or to grammar, while they have developed a great deal of planning and revision skills regarding meaning changes of the text. These changes might require a higher cognitive effort compared to revisions of errors at the surface level (Piolat et al. 2004). 
The spelling analysis of the students' final texts indicates that the participants often make the same spelling errors as children who are in the initial stages of learning how to write (Nauclér 1989). These relate to double letters for long consonants, and uncertainty about the spelling of vowels and consonants where pronunciation and orthography differ. There are very few, if any, spelling errors related to crosslinguistic transfer in the texts. This is in line with the results of the study by Odilia Breuer (2017), but not with those of the studies by Andersson (1981) and Zetterholm (2017). All participants in this study were early second language learners of Swedish who usually use Swedish at school and another language at home. Swedish is probably their strongest language, both oral and written. However, there are still a lot of spelling errors in the final texts without there being any indication of revisions in the log files. This raises questions about whether they are usually encouraged to correct spelling errors or not when writing in their second language at school. The spelling errors could also be related to the students' knowledge about spelling rules in Swedish. When teaching Swedish as a second language, spelling patterns and punctuation could tentatively be taught more explicitly in accordance with Ivanič's (2004) skills discourse.

The level of the texts corresponds, in general, to grade 2 in the assessment material used by teachers in Swedish and Swedish as a second language (Swedish National Agency for Education 2019). This means that the participants would reach the goals for writing for their age. However, this deeper analysis of their writing processes sheds light on aspects that have to be mentioned and taught. Ivanič's (2004) four discourses-the skill, the creativity, the process and the genre discourses-are didactic tools useful for teaching reading and writing. The mental process of composing a text relates to creativity processes, and it is often easier to compose something related to one's interests or experiences. For this study, the students were able to choose their own topic, and perhaps this posed a problem for some. The task did not relate to any school subject, and the texts were not intended for assessment by the teacher. This may have had an impact on the planning and transfer to writing of some students (Hayes and Flower 1980). In the studies by Asker-Àrnason et al. (2008) and Wengelin (2013), the participants followed pictures and a story about a frog, which meant a less open writing task than the one that the participants in the present study had to complete, meaning fewer revisions, especially meaning-changing revisions.

Author Contributions: This article has been co-authored. E.Z. has been responsible for data collection. Conceptualization, methodology, software, validation, formal analysis, investigation, resources, data curation, writing — original draft preparation, writing—review and editing, visualization, supervision and project administration has been divided equally between E.Z. and E.L. All authors have read and agreed to the published version of the manuscript.

Funding: This research received no external funding.

Institutional Review Board Statement: Not applicable.

Informed Consent Statement: Informed consent was obtained from all subjects involved in the study.

Data Availability Statement: Not applicable.

Conflicts of Interest: The authors declare no conflict of interest.

\section{Notes}

According to Fitzgerald (1987, p. 484), "revision means making any changes at any point in the writing process. It involves identifying discrepanies between intended and instantiated text, deciding what could or should be changed in the text and how to make desired changes, and operating, that is, making desired changes. Changes may or may not affect meaning of the text and they may be major or minor."

2 This model has primarily been influential in L1 writing research. In an updated, more sophisticated version of this model, Hayes and Berninger (2014) incorporated various levels of cognitive processing (i.e., resource, process and control levels). However, this updated model does not include a revision process as this particular process is rather seen as a specialized writing task that makes use of all the processes in the writing model (Hayes and Berninger 2014, p. 5).

3 Here, tokens refers to characters written using a keyboard. 
Keystrokes in linear text corresponds to the total number of keystrokes during the writing process, including revisions. In their study, conceptual revisions have the same meaning as meaning changes in our study.

6 This number corresponds to the total number of revised characters in the final text divided by the total number of characters in the final text.

7 The bilingual children had one Swedish-speaking parent and one Finnish-speaking parent.

8 These children did not speak Swedish at all at home; therefore, Swedish was categorized as a second language.

9 In Finland, both Finnish and Swedish are official languages. More than $80 \%$ of the population has Finnish as their L1 and only about 5\% has Swedish as their L1. Many are bilingual and speak both Finnish and Swedish, while some have Swedish as their L2. Corresponding to the time it takes to select a new key within each word.

An asterix, *, indicates that the spelling is not acceptable.

For more information about the research project, see Lindgren et al. (2015).

Bestgen and Granger (2011) studied spelling errors in authentic L2 texts taken from the International Corpus of Learner English (ICLE). The results show that spelling errors are good predictors of the quality of the texts, both when manually and automatically detected, and that sub-categorization is useful especially in manual error detection.

\section{References}

Allal, Linda. 2004. Integrated writing instruction and the development of revision skills. In Revision. Cognitive and Instructional Processes. Edited by Linda Allal, Lucile Chanquoy and Pierre Largy. Dordrecht: Kluwer Academic Publishers, pp. 139-55.

Andersson, Anders-Börje. 1981. Diktamensövningen. In Invandrarbarnen och Tvåspråkigheten. Edited by Gunnar Tingbjörn and Anders-Börje Andersson. Stockholm: Liber Utbildningsförlaget.

Asker-Àrnason, Lena, Åsa Wengelin, and Birgitta Sahlén. 2008. Process and product in writing-A methodological contribution to the assessment of written narratives in 8-12-years-old Swedish children using ScriptLog. Logopedics Phoniatrics Vocology 33: 143-52. [CrossRef] [PubMed]

Becker, Anne. 2006. A review of writing model research based on cognitive processes. In Revision: History, Theory and Practice. Edited by Alice Horning and Anne Becker. West Lafayette: Parlor Press, pp. 25-49.

Berninger, Virgina W., and H. Lee Swanson. 1994. Modification of the Hayes and Flower model to explain beginning and developing writing. In Advances in Cognition and Educational Practice. Vol 2: Children's Writing: Toward a Process Theory of Development of Skilled Writing. Edited by Earl C. Butterfield. Greenwich: JAI Press, pp. 57-82.

Berninger, Virginia W., Cheryl Yates, Ana Cartwright, Judith Rutberg, Elisabeth Remy, and Robert Abbott. 1992. Lower-level developmental skills in beginning writing. Reading and Writing: An Interdisciplinary Journal 4: 257-80. [CrossRef]

Bestgen, Yves, and Sylviane Granger. 2011. Categorising spelling errors to assess L2 writing. International Journal of Continuing Engineering Edcation and Life-Long Learning 21: 235-52. [CrossRef]

Bialystok, Ellen, Gigi Luk, and Ernest Kwan. 2009. Bilingualism, Biliteracy, and Learning to Read: Interactions Among Languages and Writing Systems. Scientific Studies of Reading 9: 43-61. [CrossRef]

Breese, Chris, Anita Jackson, and Terry Prince. 1996. Promise in Impermanence: Children writing with unlimited access to word processors. International Journal of Adolescence and Youth 6: 129-60. [CrossRef]

Bridwell, Lillian S. 1980. Revising strategies in twelfth grade students' transactional writing. Research in the Teaching of English 14: 107-22.

Chanquoy, Lucile. 2009. Revision Processes. In The SAGE Handbook of Writing Development. Edited by Roger Beard, Debra Myhill, Jeni Riley and Martin Nystrand. London: SAGE, pp. 80-97.

Cumming, Alister. 2001. Learning to write in second language: Two decades of research. International Journal of English Studies 1: 1-23.

Damerau, Fred J. 1964. A Technique for Computer Detection and Correction of Spelling Errors. Communications of the ACM 7: 171-76. [CrossRef]

De Houwer, Annick. 2021. Bilingual Development in Childhood. Cambridge: Cambridge University Press.

Faigley, Lester, and Stephen P. Witte. 1984. Measuring the effects of revisions on text structure. In New Directions in Composing Research. Edited by Richard Beach and Lillian S. Bridwell. New York: Guilford Press, pp. 95-108.

Fitzgerald, Jill. 1987. Research on revision in writing. Review of Educational Research 57: 481-506. [CrossRef]

Garlén, Claes. 1988. Svenskans Fonologi. Lund: Studentlitteratur.

Gnach, Aleksandra, Esther Wiesner, Andrea Bertschi-Kaufmann, and Daniel Perrin. 2007. Children's Writing Processes When Using Computers: Insights based on combining analyses of product and process. Research in Comparative and International Education 2: 13-28. [CrossRef]

Goldberg, Amie, Michael Russell, and Abigail Cook. 2003. The effect of computers on student writing: A meta-analysis of studies from 1992 to 2002. The Journal of Technology, Learning, and Assessment 2: 4-51.

Grejda, Gail F., and Michael J. Hannafin. 1992. Effects of Word Processing on Sixth Graders' Holistic Writing and Revisions. Journal of Educational Research 85: 144-49. [CrossRef]

Hayes, John, and Virgina W. Berninger. 2014. Cognitive processes in writing: A framework. In Writing Development in Children with Hearing Loss, Dyslexia, or Oral Language Problems: Implications for Assessment and Instruction. Oxford: Oxford University Press, pp. 3-15. 
Hayes, John, and Linda Flower. 1980. Identifying the organization of writing processes. In Cognitive Processes in Writing. Edited by Lee W. Gregg and Erwin R. Steinberg. Hillsdale: Erlbaum, pp. 3-30.

Ivanič, Roz. 2004. Discourses of Writing and Learning to Write. Language and Education 18: 220-45. [CrossRef]

Kenner, Chairman. 2004. Becoming Biliterate: Young Children Learning Different Writing Systems. Stroke-on Trent: Trentham Books.

Kenner, Chairman, Gunther Kress, Hayat Al-Khatib, Roy Kam, and Kuan-Chun Tsai. 2004. Finding the Keys to Biliteracy: How Young Children Interpret Different Writing Systems. Language and Education 18: 124-44. [CrossRef]

Lam, F. S., and Martha C. Pennington. 1995. The Computer vs. the Pen: A comparative study of word processing in a Hong Kong secondary classroom. Computer Assisted Language Learning 8: 75-92. [CrossRef]

Lindgren, Eva, Kristyan Spelman Miller, and Kirk Sullivan. 2008. Development of fluency and revision in L1 and L2 writing in Swedish high school years 8 and 9. International Journal of Applied Linguistics 156: 133-51. [CrossRef]

Lindgren, Maria, Gudrun Svensson, and Elisabeth Zetterholm. 2015. Forskare Bland Personal Och Elever. Forskningssamarbete om språkoch identitetsutveckling på en flerspråkig skola. Växjö: Linnaeus University Press.

Lindström, Eva, and Elisabeth Zetterholm. 2019. Tangentnedslag och pauser i flerspråkiga elevers skrivprocess. RASK International Journal of Langugage and Communication 49: 67-86.

Nauclér, Kerstin. 1989. Hur utvecklas stavningsförmågan under skoltiden? In Språkutveckling under Skoltiden. Edited by Carin Sandqvist and Ulf Teleman. Lund: Studentlitteratur.

Nordmark, Marie. 2014. Digitalt Skrivande i Gymnasieskolans Svenskundervisning-En Ämnesdidaktisk Studie av Skrivprocessen. Studies in Educational Science with Emphasis om Didactics 9. Doctoral dissertation, University of Örebro, Örebro, Sweden.

Odilia Breuer, Esther. 2017. Revision processes in first language and foreign language writing: Differences and similarities in the success of revision processes. Journal of Academic Writing 7: 27-42.

Piolat, Annie, Jean-Yves Roussey, Thierry Olive, and Amada Murielle. 2004. Processing time and cognitive efforet in revision: Effects of error type and of working memory capacity. In Revision. Cognitive and Instructional Processes. Edited by Linda Allal, Lucile Chanquoy and Pierre Largy. Dordrecht: Kluwer Academic Publishers, pp. 21-38.

Scardamalia, Marlene, and Carl Bereiter. 1987. Knowledge telling and knowledge transforming in written composition. Advances in Applied Psycholinguistics 2: 142-75.

Silva, Tony. 1993. Toward an understanding of the distinct nature of L2 writing: The ESL research and its implications. TESOL Quarterly 27: 657-77. [CrossRef]

Skutnabb-Kangas, Tove. 1981. Tvåspråkighet. Lund: Liber Läromedel.

Strömqvist, Sven, Kenneth Holmqvist, Victoria Johansson, Henrik Karlsson, and Åsa Wengelin. 2006. What keystroke logging can reveal about writing. In Computer Keystroke Logging: Methods and Applications. Edited by Kirk P. H. Sullivan and Eva Lindgren. Oxford: Elsevier, Studies in Writing. vol. 18, pp. 45-72.

Swedish National Agency for Education. 2019. Nationellt Bedömningsstöd i läs- och Skrivutveckling $i$ årskurs 1-3. (National Assessment Material for Elementary School Children's Reading and Writing Development in Grade 1-3). Stockholm: Skolverket.

Von Koss Torkildsen, Janne, Fröydis Morken, Wenche A. Helland, and Turid Helland. 2016. The dynamics of narrative writing in primary grade children: Writing process factors predict story quality. Reading and Writing 29: 529-54. [CrossRef] [PubMed]

Wedin, Åsa. 2021. Construction of identities in diverse classrooms: Writing identity texts in grade five. In Multilingual Literacy. Edited by Esther Odilia Breuer, Eva Lindgren, Anat Stavans and Elke Van Steendam. Bristol: Multilingual Matters, pp. $145-62$.

Wengelin, Åsa. 2013. Groooooddddan, vaaaaaar ääääär duuu? Redigeringar i barns andraspråksskrivande. In Svenskans Beskrivning 33: Förhandlingar vid Trettiotredje Sammankomsten för Svenskans Beskrivning. Edited by Jan Lindström, Sofie Henricson, Anne Huhtala, Pirjo Kukkonen, Hanna Lehti-Eklund and Camilla Lindholm. Helsingfors: Helsingfors University.

Zetterholm, Elisabeth. 2017. Barn skriver på flera språk. Educare 1: 99-117. [CrossRef]

Zetterholm, Elisabeth. 2019. Texten växer fram - om skrivprocesser hos elever i årskurs 3. HumaNetten 43: 65-86. [CrossRef] 